\title{
Development Of Smart Working Assistance Application For J\&T Express Couriers In Juwiring Klaten Branch
}

\author{
$1^{\text {st }}$ Umar Chamdani Nur, $2^{\text {nd }}$ Muqorobin \\ ${ }^{1,2}$ Institut Teknologi Bisnis AAS Indonesia Surakarta \\ 1,2J1. Slamet Riyadi No. 361 Windan, Makamhaji, Kartasura, Sukoharjo, Indonesia \\ 1 uchamdani1994@gmail.com, ${ }^{2}$ robbyaullah@gmail.com
}

\begin{abstract}
Technology applications have now been implemented in various fields, one of which is the application of goods delivery. This study aims to make it easier for couriers to classify packages based on the most optimal and most efficient addresses. The author interviewed a courier who works at J\&T Express. The author concludes that the courier is still very difficult in determining which order of packages should be delivered first, because many couriers still do not know their own territory, let alone the areas of other colleagues that have to be backed up when one of their colleagues does not work. In this study the authors compile an application that can provide solutions to assist and facilitate couriers in grouping packages by address, by utilizing several application technologies that will be used in the development of this application. In addition to sorting packages based on address, this application can display the routes of addresses to be delivered so that couriers can be more familiar with the location to be directed so that it is easier to deliver goods. The results in this study indicate that in trials with couriers it gets a very good response, but in this application there are still some shortcomings. Thus, the development of this application is very suitable for use by couriers.
\end{abstract}

Keywords - GPS, Smartphone, Application

\section{INTRODUCTION}

Technological developments continue to increase along with human needs. Technology can not be denied that it is very helpful in solving any problems that exist in everyday life. With the existence of various applications that are smart and can help with the tasks that must be done by humans.

J\&T Express is a company engaged in the delivery of goods, both shipping by land, sea or air, which was just established on August 20, 2015. In addition to package delivery, J\&T Express has free package pick-up services on the spot, so consumers no longer need come to the drop point to deliver goods and packages.

According to one courier, the delivery system is an activity to send goods because of the trade in merchandise. Sales consist of transactions for the sale of goods and services, either in cash or on credit. In general, delivery of goods is the delivery of goods from the warehouse to their destination which has been adjusted to the shipping documents that are in accordance with the requirements for handling the goods. Packages that will be sent and before the destination will usually be collected at the central warehouse for sorting per sub-district then per sub-district, after which it will be sent back to the drop point in the destination area of each shipment of goods to be immediately sent by the courier at each drop point .

To make it easier for couriers in this case, an application is needed that can collect data and separate the data so that the package is in accordance with their respective regions. This application is also to make it easier to coordinate the packages that will be sent. In this paper, we will discuss the development of a smart working assistance application for J\&T Express couriers at the Juwiring Klaten branch.

\section{RESEARCH METHODS}

To get primary data and secondary data required in the preparation of this thesis report. Primary data were obtained from direct observation to the research site and conducting interviews with stockholders, while secondary data were obtained from literature studies. Here are some of the methods used by the author, namely:

1. Data Collection Methods

The following data collection methods are as follows:

a. Interview

The interview is a method for obtaining data and information by conducting direct questions and answers with various parties related to the author's research material, and of course to find the completeness of a data that will be made into a true and accurate report. In this case the author conducted an interview with the Stackholder of the archiving division of Express Shipping Services.

b. Observation

Analyze existing problems by observing data sources and processing and collecting data from fields related to the express delivery service information system, either in the form of notes or reports.

c. Literature study

The literature study method is carried out to support the interview and observation methods that have been carried out, namely by reading and studying several sources through print and mass media. With this method, the author tries to complete the data obtained from books, journals and also scientific works related to research topics as a reference for this thesis and also to help write a report.

2. Systems Development Method

The following methods in system development are as follows:

a. System Planning

The analysis that is being built is the decomposition of a complete system into its component parts with a view to identifying and evaluating problems, obstacles that occur and expected needs.

b. System Analysis

System analysis is a stage that aims to understand the system, identify system deficiencies, and determine the needs of the system to be built. By analyzing system 
International Journal of Computer and Information System (IJCIS)

Peer Reviewed - International Journal

Vol : Vol. 01, Issue 03, November 2020

e-ISSN : 2745-9659

https://ijcis.net/index.php/ijcis/index

procedures, each system to be built can be evaluated so that a proposal can be made for system development or the construction of a new system.

c. System Design

Application designs include: HIPO, data flow diagrams, and input output designs.

d. System Implementation

Database implementation is an implementation based on database design that has been made previously. The database implementation is described in SQL (Structured Query Language).

e. System Testing

System testing includes 2 tests, namely: Functionality Testing \& Questionnaire Testing.

\section{RESULT AND ANALYSIS}

In the discussion, discussing the results of research in the form of system design as a whole are as follows : Old system problems, namely : Couriers have difficulty grouping goods and packages based on destination addresses so it takes a long time. The difficulty is when the courier will arrange the package, the courier will compare all addresses one by one with other package addresses to determine the arrangement of packages based on the closest to the farthest address. If the courier does not memorize the entire area or the address on the package, the courier will check the position of all unknown package addresses on the map or on google maps in order to determine the order. This process will be very time consuming, Couriers have difficulty finding the location of the address that has been compiled because they do not know the location of the address so the courier has to open the maps application every time they do not know the location of the package address, as a result the delivery time is longer.

While the new system is built for the breakdown of a complete system into its component parts in order to identify and evaluate problems, obstacles that occur and the expected needs. The courier will scan the barcode on the receipt to retrieve the package address from the database. Packet addresses will be sorted from closest to farthest based on the packet being scanned. The address of the scanned package will not be saved if the address is outside of the restricted courier area.

\footnotetext{
Database by Courier

CREATE TABLE `kurir` (

’login_id varchar(50) NOT NULL,

'nama` varchar(50) NOT NULL,

'password' varchar(50) NOT NULL,

id_wilayah`int(11) NOT NULL

) ENGINE=InnoDB DEFAULT CHARSET=latin1;

ALTER TABLE 'kurir`

ADD PRIMARY KEY ('login_id`),

ADD KEY `id_wilayah` ('id_wilayah`);

ALTER TABLE `kurir`

ADD CONSTRAINT 'kurir_ibfk_1’ FOREIGN KEY (id_wilayah`)

REFERENCES `wilayah` (id_wilayah`) ON DELETE CASCADE ON UPDATE CASCADE;
}

\author{
Database by Admin \\ CREATE TABLE `kurir` ( \\ ’login_id` varchar(50) NOT NULL, \\ 'nama' varchar(50) NOT NULL, \\ 'password varchar(50) NOT NULL, \\ id_wilayah`int(11) NOT NULL \\ ) ENGINE=InnoDB DEFAULT CHARSET=latin1; \\ ALTER TABLE 'kurir` \\ ADD PRIMARY KEY (’login_id`), \\ ADD KEY `id_wilayah`(id_wilayah`); \\ ALTER TABLE `kurir` \\ ADD CONSTRAINT 'kurir_ibfk_1` FOREIGN KEY \\ (id_wilayah') \\ REFERENCES `wilayah`(id_wilayah`) ON DELETE \\ CASCADE ON UPDATE CASCADE;
}

\section{Database by Employees \\ CREATE TABLE`admin` (}

’login_id varchar(50) NOT NULL,

'nama'varchar(50) NOT NULL,

'password varchar(50) NOT NULL

) ENGINE=InnoDB DEFAULT CHARSET=latin1;

ALTER TABLE `admin`

ADD PRIMARY KEY ('login_id);

Black Box testing is a functional test held in a development environment by a group of users who will use the system being built. On the part of the builder accompanies and records errors and problems felt by users. The Black Box testing conducted was on the smart working assistance application system for J\&T couriers. The test scenario describes the sequence and things tested in the smart working assistance application for J\&T couriers. The test scenarios carried out are as follows.

This test is carried out objectively to find out the user's response to the device that has been built, the test is tested directly in the field, namely in the institution concerned. The following is the assessment score and presentation range of each answer scale given using a Likert scale for each question. The following is the questionnaire that will be given.

\section{CONCLUSION}

As for this research, it can provide the following conclusions. At the end of this pentup is made in the form of conclusions and suggestions, namely as follows: Based on the results of the analysis and testing that has been carried out on the development of the Smart Working Assistance Application for Android-based J\&T Express Couriers, conclusions can be drawn based on the objectives of the development of this courierjet application. The following are the results of the development goals of a courierjet application that have been analyzed and tested so that the following results are obtained:

1. Make it easy for couriers to classify packages based on the most optimal address. Because the application can show a grouped address list automatically so that couriers no longer need to sort out one and each package. 
International Journal of Computer and Information System (IJCIS)

Peer Reviewed - International Journal

Vol : Vol. 01, Issue 03, November 2020

e-ISSN : 2745-9659

https://ijcis.net/index.php/ijcis/index

2. Make it easy for couriers to find out the location of each address on the package because the application can show each address route that must be delivered.

3. Suggestions : In building this courierjet application there are still many shortcomings. Therefore, it requires further development and refinement. As for suggestions so that the system that can be built can work properly, things should be done as follows.

4. Adding the road history information feature, which can provide information on the latest conditions of each route, such as the existence of certain roads that are ported. So that when looking for the optimal route, the application will not pass through the road in the portal.

5. Added a coverage area feature that shows the area of the area, so that the courier can find out each area's boundaries.

6. The addition of a back up courier feature, if a courier is on holiday or not working, the backing up courier can still group packages based on the courier area they are backing up.

\section{REFERENCES}

[1] Setiawan, Daryanto. "The Impact of Information and Communication Technology Development on Culture." JURNAL SIMBOLIKA: Research and Learning in Communication Study 4, no. 1 (2018): 62 . https://doi.org/10.31289/simbollika.v4i1.1474.

[2] Rusdiana, A., and moch. Irfan. Management information System. Edited by Beni Ahmad Saebani. Management information System. bandung: CV PUSTAKA SETIA, 2014.

[3] Ramjiah, Hairul, and Lamsah. "Analysis of Motivation in Increasing Employee Productivity at J\&T Express Paringin." Islamic University of Kalimantan, 2020

[4] Daeng, Intan Trivena Maria, N.N Mewengkang, and Edmon R Kalayaan. "The Use of Smartphones in Supporting Lecture Activities by Students of Manado Unsrat Fispol." E-Journal Acta Diurna 6, no. 1 (2017): 1-15.

[5] Widarma, Adi, and Hana Kumala. "DESIGN OF EMPLOYEE SALARY APPLICATION IN PT. PP LONDON SUMATRA INDONESIA Tbk. MOUNTAIN MALAYU ESTATE - ASAHAN DISTRICT. " Journal of Information Technology 1, no. 2 (2018): 166. https://doi.org/10.36294/jurti.v1i2.303.

[6] Budiawan, Tiyo, Imam Santoso, and Ajub Ajulian Zahra. "Mobile Tracking Gps (Global Positioning System) Via Sms Media (Short Message Service)," https://play.google.com/store/apps/details?id=com.msd.JTCli ent\&hl=in\&gl=US

[7] Destiningrum, Mara, and Qadhli Jafar Adrian. "Web-based Doctor Scheduling Information System Using Codeigniter Framework (Case Study: Yukum Medical Center Hospital)." Journal of Teknoinfo 11, no. 2 (2017): 30. https://doi.org/10.33365/jti.v11i2.24

[8] Muqorobin, M., \& Rais, N. A. R. (2020, November). ANALISIS PERAN TEKNOLOGI SISTEM INFORMASI DALAM PEMBELAJARAN KULIAH DIMASA PANDEMI

Journal IJCIS homepage - https://ijcis.net/index.php/ijcis/index
VIRUS CORONA. In Prosiding Seminar Nasional \& Call for Paper STIE AAS (pp. 157-168).

[9] Utomo, I. C., Rokhmah, S., \& Muslihah, I. (2020). Web Based Distribution of Zakat, Infaq, and shodaqoh (Case Study Of Surakarta City Region). International Journal of Computer and Information System (IJCIS), $1(1)$.

[10] Muqorobin, Muqorobin, Siti Rokhmah, Isnawati Muslihah, and Nendy Akbar Rozaq Rais. "Classification of Community Complaints Against Public Services on Twitter." International Journal of Computer and Information System (IJCIS) 1 , no. 1 (2020).

[11] K. Kusrini, E. T. Luthfi, M. Muqorobin and R. W. Abdullah, "Comparison of Naive Bayes and K-NN Method on Tuition Fee Payment Overdue Prediction," 2019 4th International Conference on Information Technology, Information Systems and Electrical Engineering (ICITISEE), Yogyakarta, Indonesia, 2019, pp. 125-130, doi: 10.1109/ICITISEE48480.2019.9003782.

[12] Muqorobin, M., Hisyam, Z., Mashuri, M., Hanafi, H., \& Setiyantara, Y. (2019). Implementasi Network Intrusion Detection System (NIDS) Dalam Sistem Keamanan Open Cloud Computing. Majalah Ilmiah Bahari Jogja, 17(2), 1-9.

[13] Muqorobin, M., Apriliyani, A., \& Kusrini, K. (2019). Sistem Pendukung Keputusan Penerimaan Beasiswa dengan Metode SAW. Respati, 14(1).

[14] Abdullah, Robi W., et al. "Keamanan Basis Data pada Perancangan Sistem Kepakaran Prestasi Sman Dikota Surakarta." Creative Communication and Innovative Technology Journal, vol. 12, no. 1, 2019, pp. 13-21. 